Extrême-Orient Extrême-Occident
Extrême-Orient Extrême-Occident

35 | 2013

Les astres et le destin. Astrologie et divination en Asie orientale

\title{
East (and South) Asian Traditions in Astrology and Divination as Viewed from the West
}

Les traditions astrologiques et divinatoires en Asie de l'Est (et du Sud) vues de l'Ouest

\section{Charles Burnett}

\section{OpenEdition}

\section{Journals}

\section{Electronic version}

URL: http://journals.openedition.org/extremeorient/293

DOI: 10.4000/extremeorient.293

ISSN: 2108-7105

\section{Publisher}

Presses universitaires de Vincennes

\section{Printed version}

Date of publication: 1 May 2013

Number of pages: $285-293$

ISBN: 978-2-84292-367-9

ISSN: 0754-5010

\section{Electronic reference}

Charles Burnett, «East (and South) Asian Traditions in Astrology and Divination as Viewed from the West », Extrême-Orient Extrême-Occident [Online], 35 | 2013, Online since 01 May 2016, connection on 04 May 2019. URL : http://journals.openedition.org/extremeorient/293 ; DOI : 10.4000/ extremeorient.293 


\title{
East (and South) Asian Traditions in Astrology and Divination as Viewed from the West
}

\author{
Charles Burnett
}

The articles in this book offer a fascinating panorama of the status and practice of astrology and divination in several Asian societies, including Mongolia, Tibet, India, Taiwan, Korea, Vietnam, Japan and Cambodia. In most of these cultures there is an interplay between native traditions and imported Indian or Chinese traditions. In some periods and in some places, astrology is part of the curriculum of universities, or the remit of an official bureau, at other times astrology, along with other "superstitious" arts is rigorously proscribed by the state. Some of the traditions are written, others are oral; some are state-sponsored and centred on capital cities, others are popular and rural. Sometimes numerical correspondences are at the forefront, at other times it is the symbolic forms that predominate. For all traditions (even when, as in the case of Japan, Korea and Taiwan, only a section of the tradition is studied) one gets the impression of an inheritance stretching back into the mists of time. From the point of view of someone more familiar with the Western tradition of astrology, what is interesting are the similarities and differences.

The mainstream Western tradition is remarkably consistent. It achieved canonical form in Hellenistic and Late Greek antiquity, epitomised in the works of Dorotheos, Ptolemy, Rhetorios and Theophilos. It reached an acme in ninth-century Islamic Baghdad, with the works of Masha'allah, Umar ibn al-Farrukhan, al-Kindi and Abu Ma'shar. It was introduced into Western Christian culture through translations from Arabic, and became the backbone of the European tradition, from Guido Bonatti, through Pierre d'Ailly, Marsilio Ficino, and Johannes Schoener, to William Lilly, and survives among practising contemporary astrologers as "Traditional Astrology." But this imposing tradition cannot be isolated from currents from further East. Even if one leaves aside the Mesopotamian sources for the tradition itself, one finds continuous input of Eastern origin. Indian and Iranian elements (as well as surviving Mesopotamian vestiges) were incorporated into the Arabic texts. The Indians and Iranians had 
already assimilated Greek astrology, through translations from Greek made into India in the second century AD and into Persian, under the Sassanian empire, from the early third century onwards. But there can be no doubt that distinctively Eastern elements or an Eastern colouring (recognizable in these essays) was added. Thus, to put it very broadly, just as the Indians bequeathed the war game of chess to their Western neighbours, so they contributed a distinctive 'military astrology' to the Arabs. And both the Persians and the Indians, for whom periods of enormous numbers of years were significant, contributed to the articulation of the history of mankind through cycles and divisions of cycles, whether they were the periodic returns of conjunctions of the slowest moving planets (Jupiter and Saturn), or periods of 1000 years, or the divisions of the kaliyuga of 432,000 years. The twelve signs of the zodiac, which mapped out the annual course of the Sun through the constellations, passed from Babylonia through Greece to India, and thence, through Buddhism, to all the countries on which Buddhism impinged. But, in the other direction, the divisions which mapped out the Moon's passage through the sky - the 27 or 28 lunar mansions - originating in the Chinese xiu and the Indian naksatras (with the Mongol nagsidars in between), travelled through the Islamic world to Western Europe, along with Rahu and Ketu, the Head and the Tail of the Dragon, which marked the points where the lunar orbit crossed the Sun's. And, while the mainstream tradition of Western astrology can be traced in detail through texts and translations, there are other traditions which sometimes bear more similarity to those described in these articles. $^{1}$

Western astrology is founded primarily on a written tradition. Astrologers were expected not only to draw up in written form their horoscopic charts and astrological consilia, but also to consult books. And these books were not written in verse in order to memorise them. Far from the Western ethic is the Bon tradition described by Ramble in which oral teaching is on a higher plane than written, or the composition of verse for memorizing in Taiwan described by Homola, so that even the blind man can be an expert diviner. Secondly, the teaching of this written tradition brings astrology within the realm of the physical and mathematical sciences, central to Western education. Whether in the Tetrabiblos of Ptolemy (2nd century AD), the Great Introduction to Astrology of Abu Ma'shar (late ninth century), or the De essentiis of Hermann of Carinthia (1143 AD), astrology's dynamic foundations are grounded on physical speculation, and its mathematical foundations on astronomy. The laws of causation that astrology relies on follow Aristotelian principles, and the tables

1. The most complete summary of this Western tradition is David Pingree's (1997) From Astral Omens to Astrology: From Babylon to Bikaner. Rome. 
used for determining the positions of the planets in the horoscopic chart have been drawn up by Ptolemy and his successors. Hence, astrology was included in university education as part of the course in astronomy (or sometimes medicine) within the seven liberal arts of the philosophy curriculum. ${ }^{2}$ This official teaching of astrology, which survived into the sixteenth century, bears comparison with the place of astrology in the treaching curriculum of the Buddhist university of Nālanda, and the Banaras Hindu University described by Guenzi.

But a note of caution should be sounded, since Western university education focused on a theoretical understanding of a subject, rather than on vocational training. Moreover, in the West there were no official institutes of astrology (or specifically devoted to the teaching of astrology), such as the onmyôryô which had existed in Japan since the eighth century, the Office of the Redaction of the Observation of the Clouds in Koryo Korea, the Pavilion of Paying Tribute to Heaven in Vietnam, and the Tibetan Buddhist institutes of medicine and astrology in Lhasa and Dharamsala. The modern students of Banaras Hindu University clearly wanted to learn astrology so that they could make a living from practising it. A medieval Western university student would have had to resort to extra-curricula manuals on how to draw up horoscopes, and learn his technique from a practising astrologer. These manuals proliferated. Their production reached a peak in the fifteenth century in Western Europe, and they were among the first books to be printed, while in the Islamic world they continued to be copied in manuscripts until recent times. This proliferation of astrological textbooks bears comparison with the spread of manuals of divination in Japan in the seventeenth century described by Hayek; if one can press the comparison further, a similar progression can be traced from translations (from Arabic into Latin; from Chinese into Japanese), through adaptations, to original compositions and commentaries (first in Latin and but then increasingly in the European vernaculars; in Japanese, but with increasing use of the syllabic script). Common to both traditions is the use of tables and diagrams to make the subject matter easier to assimilate. A more recent example of this phenomena is traced by Homola for Taiwan.

But alongside accounts of diffusion and state support of astrology and divination the articles in this book document their prohibition, from the early fifteenth-century destruction of divinatory books ordered by the Korean king, T'aejong (Bruneton), through the dropping by the colonial British of the science of the stars from the curriculum of Benares Sanskrit College (the predecessor of Banaras Hindu University) in 1791 (Guenzi), and the quashing of culture of

2. Olaf Pedersen (1975). "The Corpus Astronomicum and the Traditions of Mediaeval Latin Astronomy.” Colloquia Copernicana, III, Wroclaw: 57-96. 
Chinese origin by the French in Vietnam in the mid-nineteenth century (Volkov), to the forbidding of astrology and the superstitious arts by the Communists in China (Homola). The state suppression of divination is parallelled in the West in the ordenances of the French kings Charles VIII and Louis XIV (the 'Sun' king) against promulgating political predictions (particularly those of Nostradamus) which led eventually (1682) to the command for diviners to be expelled from the kingdom. ${ }^{3}$

As a practical science, in divisions of science drawn up by Arabic and Latin scholars, astrology is ranged alongside medicine, physiognomy, dreaminterpretation, talismans, magic and alchemy, as the practical branch of physics (the physical works of Aristotle being the theoretical branch). Whether the same idea underlies the Bon division of sciences in which astrology is one of the 'external sciences' is not clear. In astrological practice, to the extent that the West and East are heirs to the same traditions, one can identify common elements; e.g., in the drawing up of birth horoscopes. The Tibetan Bonpo horoscope is similar to a western horoscope except that, in common with Buddhist beliefs, it includes past and future lives, as well as the current life of the new-born.

The canonization of astrology by Arabic and Latin philosophers, as a respectable science alongside astronomy, is concomitant upon separating it from other forms of divination. To start off with, practising astrologers are castigated for not knowing the science properly - and perhaps never being able to gain sufficient knowledge, since no one can expect to experience the full range of effects of the stars within one lifetime, or even over several lifetimes. But, more seriously, scientific or mathematical astrology is divided off from other forms of divination, and from magic in which the stars are employed. For example, in the mid-thirteenth-century text called the Speculum astronomiae ("The mirror of the science of the stars"), in which the author separates those books which are licit in astronomy and astrology from those which are illicit, talismans which engage the purely natural forces of the stars are allowed, but those which employ mysterious symbols and incomprehensible words, and suffumigations and the invocations of spirits, are disallowed.

A whole subterranean tradition of Western divination and magic draws on these "spiritual" forces in the universe, and it is perhaps these that are closer in character to, if not linked directly, with several of the traditions described in this book. ${ }^{4}$ One corpus of texts, which purports to be Aristotle's advice to

3. The sequence of ordenances is summarised in Jean-Patrice Boudet, Le "Recueil des plus celebres astrologues” de Simon de Phares, 2 vols, Paris, 1991-9, II, p. 308.

4. A synthetic account of all the varieties of astrology, divination and magic in the European Middle Ages is provided by Jean-Patrice Boudet (2008) Entre science et nigromance: astrologie, divination et magie dans l'Occident médiévale (XII ${ }^{e}-X V^{e}$ siècle). Paris. 
his pupil, Alexander the Great, taking the form of the teaching of the ancient sage Hermes (hence called the "Pseudo-Aristotelian Hermetica"), ${ }^{5}$ includes the analogy of the parts of the universe with the body of man (as in Pan Gu, the first creature in Chinese mythology), ${ }^{6}$ and lists the many names of the spirits that should be invoked when making talismans, and the suffumigations and magic symbols that should be used, alongside the prayers to the spirits. It is significant that this corpus also favours the lunar mansions over the signs of the zodiac. Lunar mansions appear as the major object of celestial observation in Islamic and Christian works on weather forecasting, but also, tellingly, in these texts of magic. ${ }^{7}$ They have no role in Western mainstream astrology.

Another Western current is that of the "correspondences" between talismans, stars, stones and plants, as detailed in the Book of Hermes about the 15 Stars, the 15 Stones, the 15 Herbs and the 15 Images (Talismans) translated from Arabic into Latin in the twelfth or thirteenth century, and the Cyranides, of which Greek, Arabic and Latin versions are extant, which continue a Babylonian genre of "stone, plant and tree" (assigned to a particular month), but which also reflect the association of animals with constellations in Mongol and Chinese astrology.

Another very characteristic phenomenon of Chinese cosmology is the belief that the events in the sky reflect the actions of the emperor. Bruneton refers to the importance of this belief in Koryo Korea, in which the behaviour of the heavenly bodies corresponds to the degree of goodness of the politics of the ruler (the theory of "the resonance between heaven and man"); hence, the astrologers were obliged to observe any irregularities or strange phenomena in the sky. Their observations are comparable in procedure and purpose to the omen-watching of the ancient Babylonians. But even in the West, outside mainstream astrology, a similar idea can be found. In her medical work, Cause et cure ("Causes and Cures"), the mid-twelfth century mystic and nun, Hildegard of Bingen, asserted that human activity is reflected in the heavens: "The stars from time to time show forth many signs responding to the conditions of men in their actions at the time. But they do not show future things or the thoughts of men, but only

5. Kevin van Bladel (2009). The Arabic Hermes: from Pagan Sage to Prophet of Science. Oxford.

6. Compare the Chinese analogy described in Vivienne Lo (2008). "Heavenly Bodies in Early China: Astro-Physiology in Context," in Anna Akasoy, Charles Burnett and Ronit Yoeli-Tlalim (eds.), Astro-Medicine: Astrology and Medicine, East and West. Florence: 143-188 (especially: 144-145), with the Arabic (and hence Latin) analogy described in Charles Burnett, "The Kitab al-Istamatis and a Barcelona Manuscript," in Charles Burnett (1996), Magic and Divination in the Middle Ages: Texts and Techniques in the Islamic and Christian Worlds. Aldershot, article VII, especially: 9-10.

7. See Charles Burnett (2004). "Lunar Astrology," Micrologus, 12: 43-133. 
what man is doing now, when he manifests his will in speech or action. For the air takes up these (words and actions) and, in turn, passes them on to the stars which immediately show forth the actions of men correspondingly... So, when he transgresses justice through his bad actions, he distresses the Sun and the Moon and obscures them with clouds, with the result that, responding to him, they react with storms, heavy rain or drought." 8

One element that is striking about Western magic is its syncretism. The magical handbook drawn up in Arabic in al-Andalus in the early eleventh century, called Ghayat al-Hakim ("The Aim of the Wise Man") in Arabic, and Picatrix in its Latin translation, lists the Greek, Sanskrit, Persian, Arabic and Roman names of the planets, and combines magical recipes of both Egyptian and Babylonian ("Chaldean") origin. ${ }^{9}$ Similarly, as Ramble shows in the dating of events in Bonpo texts, we find combinations of the Zhangzhung language name, the Mongolian month number, the Sanskrit name, the sign of the zodiac, the Chinese name, the system of Chinese divination, the seasonal division into thirds, the corresponding link in the twelve-fold nexus of dependent origination, the lunar mansion, and the "epithet." Japanese books, in turn, bring together Chinese, Indian and native Japanese divination, and no contradiction is implied by using different systems concurrently.

Another common line between Eastern practices and Western magic is the prominence of the master-pupil transmission, in which the master must only pass on his knowledge to a worthy pupil, who will not broadcast the knowledge to a general public (as in Japan before the 17th century, exemplified by the Hoki naiden of the fourteenth century). A continuous succession of masters to pupils (in Islam referred to as the isnad) can account for the antiquity and authenticity of the doctrine, though in the Buddhist context, this succession has the added advantage of being possible through reincarnation.

It is in these magical-astrological texts in the West that the animation of the universe, which Baumann recognizes as being part of ancient Egyptian, Mesopotamian and Iranian traditions, survives. There may not be a god for each minute and each second as in the Bon tradition, but the planets have their days and their hours (even thirds of hours), and in performing magic, at least, it is necessary to observe the precise time of the action. And if colours were secondary in the practice of Western magic, the shapes of the magical symbols

8. Laurence Moulinier (2003). Hildegard of Bingen, Cause et Cure. Berlin: 38.

9. David Pingree (1980). "Some of the Sources of Picatrix," Journal of the Warburg and Courtauld Institutes, 43: 1-15. 
(whether magic squares, or "characteres" of the planets, or the mandala-like symbols in the ars notoria) were important. ${ }^{10}$

Parallels too can be drawn between the Yi Ching hexagrams, and Western geomancy (not to be confused with Chinese geomancy), in which tetragrams (rather than trigrams or hexagrams) of four layers in a binary system of one or two points in each layer, are arranged on a "geomantic horoscope" of 16 compartments. ${ }^{11}$ Numbers, in themselves, have symbolic values which are shared in the East and West. Two numbers appear prominently in this book, four and nine. The concomitant of the number four is the four-sided square. As Baumann suggests, because man conceives the world in which he is placed as having four sides (and for the Chinese, man was placed on a rectangular earth), it was natural for Chinggis Khan to think that world domination consisted of ruling the four directions, and should be divided amongst four sons. The "number square" (or "magic square") in which the numbers in each row and along the diagonals all add up to the same value, appears in China, and then in traceable traditions between Arabic, Greek and Latin. The Western tradition places in parallel the four seasons with the four elements, the four humours, the four ages of man etc. This universal fourness is challenged by a three-humour system in Ayurvedic medicine, and the five agents of the Chinese, but a division into four would seem to be natural to the human mind. The significance of nine is less intuitive, but, as Ramble shows, all the Bonpo teachings are organised in a ninefold hierarchy, and from the nine orifices of the Cosmic Turtle derive the nine magic numbers. These are not the nine numerals of the Indian system, but rather the first 9 powers of 10. The powers of ten also appear in the columns of the Western abacus table, from the late tenth century onwards, but this time the columns are marked with the "new" nine Indian numerals. ${ }^{12}$ The symbolic power of nine is described in a later Latin account of the Indian numerals - "the Toledan regulae" of the midtwelfth century - in which it is stated that "in both celestial and earthly things,

10. Colours, along with significant thirds of hours, and the 27 lunar mansions, feature in the Alchandreana, a popular tradition of Arabic and Western astrology, independent of mainstream traditional astrology: see David Juste (2007). Les Alchandreana primitifs: étude sur les plus anciens traités astrologiques latins d'origine arabe ( $x^{e}$ siècle). Leiden. The Ars notoria and the Western "mandala" tradition have both been dealt with by Julien Véronèse (2007). L'Ars notoria au Moyen Âge: introduction et édition critique. Florence and (2012) L'Almandal et l'Almadel latins au Moyen Âge: introduction et éditions critiques. Florence.

11. Thérèse Charmasson (1980), Recherches sur une technique divinatoire: la géomancie dans l'occident médiéval. Geneva.

12. For examples, see Menso Folkerts (1996). "Frühe Darstellungen des Gerbertischen Abakus.” In R. Franci, P. Pagli and L. Toti Rigatelli (eds), Itinera mathematica. Studi in onore di Gino Arrighi per il suo 90a compleanno. Siena: 23-43. 
both bodies and spirits seem to have been formed and put in order according to the model of the nine: for nine are the spheres of celestial bodies, nine are the orders of celestial spirits and nine are the temperaments of all bodies." ${ }^{13}$ Both the East and the West list "nine" planets in that they add to the Moon, Mercury, Venus, the Sun, Mars, Jupiter and Saturn, the Head and the Tail of the Dragon (Rahu and Ketu) as the lunar nodes that travel round the ecliptic in the same way as the other planets. It is not by chance that the simplest and most powerful of the number squares also has nine compartments $(3 \times 3)$.

The sortilege described by Bizot which leads to a figure in the Ramayana, which warns of a certain misfortune that can be warded off by making a talisman of the figure concerned, placed in a certain compass direction, is a more complex version of the genre of fortune-telling in the West whereby one is led, by a series of tables to the figure of a Biblical patriarch, or a bird, or a lunar mansion, which would then tell one what the future held in store. ${ }^{14}$

Not all mantic crafts in the West involved numinous elements. Whereas, for the Mongols and Chinese, the shoulder blade of a grazing animal cracked at a time and in a direction directly mandated by God (Baumann), the same blade in the West revealed the future simply by natural signs in specific places on the blade. Also, the "underground" traditions and mainstream Western astrology overlapped and impinged on one another. In connection with Western medical writings it is common to find a figure representing the "melothesia" - the picturing of each of the signs of the zodiac on the human body, from Aries on the head to Pisces on the feet. Its avowed purpose is to prevent the doctor from cutting the body (phlebotomy) when the Moon is in the sign of the zodiac representing that part of the body - a very practical and scientific procedure. ${ }^{15}$ But the analogy between the microcosm and macrocosm cannot be lost in this figure (after all, purely textual instructions for phlebotomy could be given), and it may not be coincidental that the same microcosm-macrocosm analogy is used in indicating the acupuncture points in Chinese medicine. Just as the Moon is observed passing through each of the signs of the zodiac in the Western "zodiac man" so, in the East, the lunar cycle directs the vital force which flows round the body. The assignation of the seven openings of the head to the seven planets, is common to the mainstream works of Abu Ma'shar and al-Qabisi (10th century)

13. Charles Burnett, Ji-Wei Zhao and Kurt Lampe (2007). "The Toledan Regule (Liber Alchorismi, Part II): A Twelfth-Century Arithmetical Miscellany." Sciamus, 8: 141-231 (see 209).

14. J. Bolte (1903). Zur Geschichte der Losbücher, appendix to G. Wickram, Werke, IV. Stuttgart: 276-348.

15. See Hilary M. Carey, "Medieval Latin Astrology and the Cycles of Life," in AstroMedicine: Astrology and Medicine, East and West (n. 4 above): 33-74 (especially: 37-41). 
and to the Pseudo-Aristotelian Hermetica. Moreover, the Speculum astronomiae classifies talisman-making as part of the astrological genre of "elections" or catarchic astrology. The choosing of the right time for an activity, to ensure success, is the most magical part of astrology, and it is no coincidence that this has close parallels in the practices described in this volume.

So, the connections, both in spirit and in practice, of Western and Oriental astrology and divination may be stronger than one might initially suspect. The main impression given by this book is of the spread of ideas over long periods of time and from one culture to another, whether of Middle Eastern symbols shared by Mongols, along with their use of a language written in an Aramaic script (Baumann), the migration of the "invisible stars" Rahu and Ketu from India to China and Korea (Bruneton), or the passage of a Hindu epic to Cambodia (Bizot). Sometimes the streams flow together, as in the examples of Bon culture; at other times they are kept apart, as in the case of the Ramayana in Cambodia, which was not adapted to the Chinese animal years. These essays offer a challenge to extend the scope of these lines of transmission to include the West, and to follow streams such as the sexagenarian system, the symbolism of the number 9 , and the lunar mansions. They invite us to explore what social and political contexts led to the support or rejection of astrology and divination in general. 